IZA DP No. 6884

The Impact of Managerial Change on Performance:

The Role of Team Heterogeneity

Sandra Hentschel

Gerd Muehlheusser

Dirk Sliwka

September 2012 


\title{
The Impact of Managerial Change on Performance: The Role of Team Heterogeneity
}

\author{
Sandra Hentschel \\ Bielefeld University \\ Gerd Muehlheusser \\ University of Hamburg, \\ IZA and CESifo \\ Dirk Sliwka \\ University of Cologne, \\ IZA and CESifo
}

\section{Discussion Paper No. 6884 \\ September 2012}

\author{
IZA \\ P.O. Box 7240 \\ 53072 Bonn \\ Germany \\ Phone: +49-228-3894-0 \\ Fax: +49-228-3894-180 \\ E-mail: iza@iza.org
}

\begin{abstract}
Any opinions expressed here are those of the author(s) and not those of IZA. Research published in this series may include views on policy, but the institute itself takes no institutional policy positions. The IZA research network is committed to the IZA Guiding Principles of Research Integrity.

The Institute for the Study of Labor (IZA) in Bonn is a local and virtual international research center and a place of communication between science, politics and business. IZA is an independent nonprofit organization supported by Deutsche Post Foundation. The center is associated with the University of Bonn and offers a stimulating research environment through its international network, workshops and conferences, data service, project support, research visits and doctoral program. IZA engages in (i) original and internationally competitive research in all fields of labor economics, (ii) development of policy concepts, and (iii) dissemination of research results and concepts to the interested public.
\end{abstract}

IZA Discussion Papers often represent preliminary work and are circulated to encourage discussion. Citation of such a paper should account for its provisional character. A revised version may be available directly from the author. 
IZA Discussion Paper No. 6884

September 2012

\section{ABSTRACT \\ The Impact of Managerial Change on Performance: The Role of Team Heterogeneity ${ }^{*}$}

When a key responsibility of a manager is to allocate more or less attractive tasks to subordinates, these subordinates have an incentive to work hard and demonstrate their talents. As a new manager is less well acquainted with these talents this incentive mechanism is reinvigorated after a management change - but only when the team is sufficiently homogenous. Otherwise, a new manager quickly makes similar choices as the old one did. We investigate this hypothesis using a large data set on coach dismissals in the German football league where the selection of players is indeed a key task of the coach. Indeed, we find substantial evidence that coach replacements enhance team performance (only) in homogenous teams. Moreover, from a methodological point of view, we argue that there is typically a negative selection bias when evaluating succession effects, which might reconcile previous findings of no (or even negative) effects with the vast number of dismissals observed in reality.

JEL Classification: D22, J44, J63

Keywords: managerial succession, teams, heterogeneity, tournaments

Corresponding author:

Gerd Muehlheusser

University of Hamburg

Department of Economics

von-Melle-Park 5

20146 Hamburg

Germany

E-mail: gerd.muehlheusser@wiso.uni-hamburg.de

\footnotetext{
*Financial support from the State of North Rhine-Westphalia (NRW), Ministry for Family, Children, Culture and Sport (MFKJKS) is gratefully acknowledged. Moreover, we thank Impire AG for kindly providing a large part of the data used in the paper and Merle Gregor, Michaela Buscha, Stefanie Kramer, Dennis Baufeld, Dennis Hebben, and Uwe Blank for excellent research assistance. We also benefitted from the comments received when presenting the paper at the 2012 workshop on "Personnel Economics" (PÖK) at the University of Paderborn, as well as the workshop on "Football and Finance" at the University of Münster.
} 


\section{Introduction}

In many organizations, the dismissal of a manager is typically triggered by unsatisfactory performance of the unit (e.g. team, subdivision) for which the manager is responsible. Consequently, in replacing the current manager by a new one, executives hope for enhanced performance. But whether and how a new manager can affect a firm's or a team's performance intricately depends on the role of the manager within the organization. In this paper we study a particular channel through which a manager can affect performance, namely through the selection of team members and its effects on within-team competition for attractive positions.

Höffler and Sliwka (2003) have analyzed within-team competition in a theoretical model in which a manager picks among team members to fill an important position. The paper builds on Lazear and Rosen's (1981) tournament theory and endogenizes a manager's selection choice under incomplete information about individuals' ability or talent. When a manger has been in place before she knows the abilities of the team members quite well and therefore should have a clear idea in mind who should be picked. In turn, competition for being selected is weaker. When, however, a new manager is brought in from outside this new manager knows less about the respective abilities and in turn, within-team competition is reinforced. But whether a management replacement can indeed trigger such a push in incentives crucially depends upon the composition of the team. In particular, when team members differ strongly in their abilities the new manager will most certainly pick the same individuals as the old manager had - in turn dismissals only have weak effects in this respect. But if the team composition is more homogenous, management replacements are more effective in reinvigorating within-team competition.

On a more general level, this prediction builds on a theoretically robust mechanism that has been established across a large number of models on asymmetric contests and tournaments, in which it has been shown that equilibrium efforts tend to be the higher the 
more symmetric (and hence the more competitive) the contest. ${ }^{1}$ From this perspective the dismissal of a manager can be viewed as an instrument to reduce the asymmetries in contest.

We study this question empirically in an area where the selection of subordinates for important tasks is one of the core responsibilities of a manager, namely in professional team sports. To do this we are using a large data set on the German Bundesliga, one of the biggest soccer leagues in the world. A key task of a head coach in soccer is the selection of the starting line-up of 11 players for each game from a larger number (on average 25) players employed by the respective club. As the players' career advancement, their popularity and often also their remuneration depend crucially on their appearance in this starting line-up, competition among team members for these positions is an important element of team sports. The dismissal of the coach now should have a substantial impact on the nature of this within-team competition. It is the key purpose of this paper to test empirically whether indeed dismissals have a stronger effect on performance in teams which are homogenous with respect to the abilities of the team members.

In general the empirical evaluation of management dismissals in general is non-trivial because of a number of caveats: First, there is often a lack of available performance measures for managers' unit of control. In addition, managerial change either occurs rarely and/or is often accompanied by further changes in the surrounding conditions, which obscures the identification of the causal succession effect. Furthermore, organizations will typically be heterogenous with respect to a number of crucial dimensions which makes it difficult to assess the contribution of a single manager. And last but not least, dismissal decisions are unlikely to be random, but often occur after a period of low performance. When part of the actual performance is outside a manager 's control ("luck"), then the organization's expected performance may increase after managerial

\footnotetext{
${ }^{1}$ See e.g. O'Keeffe, Viscusi, and Zeckhauser (1984), Lien (1990), Baik (1994), Gradstein (1995), Nti (1999), Clark and Riis (2000), Szymanski and Valletti (2005), Moldovanu and Sela (2006), and Feess, Muehlheusser, and Walzl (2008). Moreover, the literature has also considered the issue of excluding weak contestants as to not dilute the incentives of their stronger counterparts (see e.g. Fullerton and McAfee, 1999; Taylor, 1995; Nalebuff and Stiglitz, 1983).
} 
change simply because of mean reversion. ${ }^{2}$

In response to these difficulties, a major part of the existing literature has aimed at measuring succession effects in the context of professional team sports. Apart from being of interest in its own right, the sports sector is long recognized as a valuable "labormarket laboratory" (Kahn, 2000) and it is particularly well-suited for the analysis of succession effects. In particular, in European soccer, managerial changes occur rather frequently and, in most cases they occur within a season (i.e. between two match days). In the German Bundesliga, in a given season of our observation period 1993 - 2009, on average $48 \%$ of all teams experienced at least one within-season managerial change. A key benefit of within season replacements for the purpose of the evaluation of dismissal effects is that most other crucial determinants for team success (e.g., composition of roster or team budget) remain constant between two match days. ${ }^{3}$

There now exists a large number of empirical studies which have attempted to assess the effects of management changes in professional sports. Early studies typically use seasonal data from U.S. sports leagues (and hence mainly consider between-season managerial change), and the evidence is mixed: Grusky (1963), Theberge and Loy (1976), and Allen, Panian, and Lotz (1979) do find a negative relationship between managerial change and the performance in different U.S. sports leagues. Other studies do not find a statistically significant effect and interpret this as evidence in favor of 'ritual scapegoating' (Gamson and Scotch, 1964; McPherson, 1976; Brown, 1982). A final set of studies does find a mild positive effect (Gamson and Scotch, 1964; Fabianic, 1994; McTeer, White, and Persad, 1995) where the measured effects are typically stronger in the short run and often vanish shortly after the replacement takes place. ${ }^{4}$ While the older studies

\footnotetext{
${ }^{2}$ A similar phenomenon has become known as "Ashenfelter's dip" in the context of evaluating labor market training programs, where trainees' often exhibited pre-program earnings below average, thereby obscuring the measurement of the effectiveness of the training program (see e.g. Ashenfelter, 1978; Heckman, LaLonde, and Smith, 1999).

${ }^{3}$ In our view, this makes the European sports sector particularly attractive for the analysis of succession effects as compared to U.S. sports leagues because for the latter, (the typical) between-seasons replacements are often accompanied by changes of other crucial variables such as the team's roster.

${ }^{4}$ There also exists a strand of literature concerned with the reverse relationship, i.e. with the impact of current performance on the likelihood of a managerial change (see e.g. Porter and Scully, 1982; Scully, 1994; Audas, Dobson, and Goddard, 1999; Barros, Frick, and Passos, 2009).
} 
often do not fully account for performance prior to dismissals and are prone to meanreversion effects (i.e. if a coach is dismissed after a series of losses the probability of a performance increase is necessarily larger). In more recent studies match-level data is used which allows to directly control for the prior performance of each team and account for mean reversion. In particular, the large bulk of studies of different European soccer leagues either find detrimental (e.g. Bruinshoofd and ter Weel, 2003; Audas, Goddard, and Dobson, 1997; Audas, Dobson, and Goddard, 2002) or no effects (e.g. De Paola and Scoppa, 2012), while only de Dios Tena and Forrest (2007) provide some evidence for performance increases after a dismissal. But surprisingly, most of these studies still lack a clean discussion of biases due to the endogeneity of coach dismissals beyond potential mean-reversion effects.

Our paper adds to the literature in two respects. First of all, we analyze in more detail potential selection effects and argue that the typical approaches (including our own) tend to underestimate the effects of coach dismissals. The reason is that the effect of a dismissal is typically identified by comparing the average performance of teams dismissing the coach with the performance of non-dismissing teams who exhibit similar values for a set of observable variables. This would identify a causal effect if the (counterfactual) performance of teams with dismissals was identical to the performance of non-dismissing teams with the same set of observables. As we show in a simple model in which the executives who decide on the dismissal of the manager receive a private signal that contains additional information on the benefits of a dismissal, this will typically not be the case under very plausible assumptions: the fact that a team dismissed a manager reveals unfavorable information about the future performance without a dismissal. Hence, the conditional expectation about counterfactual performance of the team who dismissed the coach should therefore be smaller than the performance of the teams who did not dismiss the coach in the same situation. In turn, the typical estimates should give a lower bound on the true effects of coach dismissals. Hence, from these considerations we can reconcile the two apparently contradictory observations in the previous literature i.e. that coach dismissals were estimated to be mostly useless, but that there are still so 
many of them..$^{5}$

But more importantly, while nearly all other studies investigate the average consequences of coach dismissals in soccer, our approach is to study under which contingencies a dismissal can be expected to be beneficial. In particular we study the importance of the team composition prior to the dismissal. Indeed we find that teams who replaced their coach significantly increase their performance as compared to other teams exhibiting the same set of observables - but only when the team is sufficiently homogenous prior to the dismissal. Given the above arguments that we identify a lower bound to the true effects, we conclude that coach dismissals on average have substantially positive performance effects in homogenous teams. Moreover, we also investigate the effect of coach dismissals on the performance of individual players and show that individual performance increases to a stronger extent in homogenous teams and among players on the contested ranks, i.e. for those players who compete for a position in the starting line-up. To the best of our knowledge, there has been no empirical evidence so far concerning the impact of heterogeneity in the context of dismissals and our analysis reveals that this is a key factor determining the success of a replacement. Moreover, our results are consistent with recent findings from the empirical literature on asymmetric contests which often finds a negative correlation between effort levels and the degree of heterogeneity of contestants (see e.g Schotter and Weigelt, 1992; Orrison, Schotter, and Weigelt, 2004; Lynch, 2005; Brown, 2011; Sunde, 2009; Berger and Nieken, 2010; Nieken and Stegh, 2010).

The remainder of the paper is organized as follows: Section 2 lays out empirical framework. In Section 3 we present our empirical results concerning the impact of coach dismissals on the performance of teams and individual players. Section 4 discusses our findings and concludes.

\footnotetext{
${ }^{5}$ Note that dismissals are rather expensive for teams as the sacked manager is entitled to receive his wage until his contract would have expired. In many cases, teams and managers agree on a severance payment in exchange for mutually canceling the contract.
} 


\section{Empirical Framework}

\subsection{Institutional Background and Data}

Our aim is to estimate to what extent the effect of a coach dismissal depends upon team heterogeneity. But a key challenge is of course the potential endogeneity of the dismissal itself. Coach dismissals are not exogenously imposed and will typically be driven by the (observed) performance history of a team but may also be influenced by (unobserved) private information of the club's management on the future performance of the team. Hence, a careful discussion of potential selection effects is of crucial importance for any study of management dismissals with observational data. But first, it is important to understand the structure of the data we use and the basic econometric approach.

The German Bundesliga consists of 18 teams, and each team plays twice against each other team (one home match each) resulting in 34 match days per season and 306 matches overall. In each match, a winning (losing) team is awarded 3 (0) points. In case of a draw, each team is awarded 1 point and teams are ranked according to their accumulated points. ${ }^{6}$ At the end of the season, the team with the highest number of points wins the championship (there are no playoffs), while the two resp. three teams with the lowest number of points are delegated to the second division and replaced by the best two resp. three teams from that division. ${ }^{7}$ Both the league winner and the second best team are automatically qualified to participate in the highly prestigious UEFA Champions League in the subsequent season; the third best team has also the chance of participation by prevailing in a preliminary tournament against corresponding teams from other European leagues. The teams ranked fourth and fifth participate in the UEFA Euro League (so does the third best team, in case it fails to quality for the Champions League). The incentives (both financially and with respect to reputation) to

\footnotetext{
${ }^{6}$ When several teams have accumulated the same number of points, the goal difference is used as the tie-breaking rule.

${ }^{7}$ For the seasons $1992 / 93-2007 / 08$, the three teams at the bottom were relegated. For the season $1991 / 92$, the league was enlarged to 20 teams (due to the German re-unification) and four teams were relegated. As of season 2008/09, the team ranked third to last and the team ranked third in the second division compete in two extra matches for the final Bundesliga slot for the next season.
} 
qualify for one of the two UEFA leagues are very strong, the same is true for avoiding relegation. ${ }^{8}$

The unit of observation in our data set is a specific match. The data set contains all matches played in the German Bundesliga for the 17 seasons from 1993/94 until 2009/10 (9 matches played on each of 578 match days leading to a total of 5.202 matches). For each match, we have detailed information about match- and team-specific characteristics, as well as the involved managers and players. For most of the analysis, the dependent variable is the number of points $y_{i j t}$ won by the home team in a match between home team $i$ and away team $j$ at match day $t$. As there are three possible match outcomes, home team win, draw or away team win, resulting in $3(0), 1$ (1) or 0 (3) point(s), respectively, for the home (away) team, both teams have a strictly monotone (but reversed) preference order with respect to it.

\subsection{Identification and Selection Bias}

We estimate by OLS a number of regression models of the following form ${ }^{9}$ :

$$
\begin{aligned}
y_{i j t} & =\alpha+\beta_{1}^{\text {Home }} \cdot \text { new }_{i t}^{\tau}+\beta_{2}^{\text {Home }} \cdot \text { new }_{i t}^{\tau} \times \text { het }_{i t}+\beta_{3}^{\text {Home }} \cdot \text { het }_{i t}+X_{i t}^{\prime} \gamma^{\text {Home }}+Y_{i t}^{\prime} \delta^{\text {Home }} \\
& +\beta_{1}^{\text {Away }} \cdot \text { new }_{j t}^{\tau}+\beta_{2}^{\text {Away }} \cdot \text { new }_{j t}^{\tau} \times \text { het }_{j t}+\beta_{3}^{\text {Away }} \cdot \text { het }_{i t}+X_{j t}^{\prime} \gamma^{\text {Away }}+Y_{j t}^{\prime} \delta^{\text {Away }}+\varepsilon_{i j t} .
\end{aligned}
$$

The variables $h e t_{i t}$ and $h e t_{j t}$ are measures for the heterogeneity of each team, $X_{i t}$ and $X_{j t}$ are vectors of team and time specific control variables, while $Y_{i t}$ and $Y_{j t}$ contain different measures for the respective team's past performance (all explained in detail below). The

\footnotetext{
${ }^{8}$ For example, the UEFA Champions League earned Bayern Munich an additional 58 Mio Euro in the season 2009/2010, as compared to an average Bundesliga team's budget of 39.5 Mio Euro for that season. The numbers for the Euro League are smaller, but still significant. On the other side of the spectrum, relegation typically comes along with severe budgets cuts, which is due to lower TV fees (on average 18.5 million Euro per season in the Bundesliga versus 4.9 million in the lower division), gate revenues and merchandizing revenues. As a consequence, teams are forced to sell some (in many cases most) of their best players.

${ }^{9}$ Estimating ordered probit models leads to virtually identical results. See e.g. Angrist and Pischke (2008, pp. 107) for a critical discussion on the use of linear and non-linear models when the outcome of interest is a limited dependent variables.
} 
dummy new $w_{i t}^{\tau}\left(n e w_{j t}^{\tau}\right)$ indicates whether, prior to match day $t$, the home (away) team's manager is "new" in the sense that he has been hired within the last $\tau$ home (away) matches of the home (away) team. Throughout, we will consider three different time horizons $\tau \in\{2,4,6\}$ for the effects of managerial change to materialize. Overall, there are 197 dismissals in our sample, out of which 146 occurred within a season. In 26 out of these 146 cases, the new manager was (and was ex ante known to be) an interim solution, supposed to step down as soon as the "true" successor was available. These were dropped from the main analysis, which leaves us with 120 within-season dismissals. ${ }^{10}$

As for the causal effect of a dismissal, it is crucial to consider the underlying conditional independence assumption. To save on notation, define $X_{i j t}=\left(X_{i t}, X_{j t}, n e w_{j t}\right)$ and $Y_{i j t}=\left(Y_{i t}, Y_{j t}\right)$ which contain all relevant match-specific covariates. Moreover, denote by $y_{i j t}(1)$ the outcome for team $i$ upon dismissing its manager, and by $y_{i j t}(0)$ the (potentially counterfactual) outcome when there is no dismissal. Then, our approach allows is to identify a causal effect of a dismissal $y_{i j t}(1)-y_{i j t}(0)$ if

$$
E\left[y_{i j t}(0) \mid \text { new }_{i t}=1, X_{i j t}, Y_{i j t}\right]=E\left[y_{i j t}(0) \mid n e w_{i t}=0, X_{i j t}, Y_{i j t}\right] .
$$

That is, conditional on the observed control variables the counterfactual performance of dismissing teams in case of non-dismissal should be equal to the performance teams who did not dismiss the coach in the same situation. Intuitively, the effect of a coach dismissal is here estimated by comparing the performance of teams who recently dismissed the coach with the performance of other teams who did not dismiss the coach under the same set of observables.

A first potential endogeneity issue that has already been acknowledged in the previous literature is that dismissals are typically triggered by low team performance in the last games prior to the dismissal. A performance increase after a dismissal may then, for instance, be simply be a mean reversion phenomenon. To account for this we follow

\footnotetext{
${ }^{10}$ In our sample, the average spell duration of interim managers was 2.3 matches. In section 3.3 below, we will use the performance of teams playing under interim managers as a robustness check for our main results.
} 
a lagged-dependent variable approach, and the vectors $Y_{i t}$ and $Y_{j t}$ contain the following variables for each team: ${ }^{11}$ First, we take into account a team's long-term performance history, measured by the average league position in the last three seasons (PerfHist). Second, as a measure for a team's performance in the current season, we use the average number of points accumulated in the season up to the match under consideration. Because there is typically a considerable difference between a team's performance in home and away matches (see Table 1 below), we distinguish between the two match types (homePerf and awayPerf) for both the home and the away team. Finally, as each team's exact sequence of outcomes in the most recent games can be crucial for both the decision to dismiss a coach and the pattern of mean reversion - we employ a saturated approach concerning the most recent performance by including dummy variables to indicate its exact performance history in the last four matches ${ }^{12}$, thereby allowing for non-linearities. In this sense, we come close to a matching approach comparing teams with identical short-term performance histories. ${ }^{13}$

Last, but not least, the vectors $X_{i t}$ and $X_{j t}$ in Eqn. (1) contain each team's respective relative annual budget (budget), that is, its absolute budget divided by the average absolute budget in the league in a given season. We use this as a measure for a team's ability to attract top players. ${ }^{14}$ Finally, we include a dummy variable indicating whether a match is crucial for the respective team. ${ }^{15}$

\footnotetext{
${ }^{11}$ An alternative strategy would be to use team fixed-effects. However, a fixed effects model with lagged dependent variables leads to inconsistent estimates, see Nickell (1981) and also Angrist and Pischke (2008, pp. 243). As controlling for recent performance prior to the dismissal is very important to reduce selection issues, we prefer the lagged dependent variable approach. However, fixed effects models lead to qualitatively very similar results.

${ }^{12}$ As shown in panel (a) of Figure 4 below, teams dismissing a coach indeed exhibit a particular performance pattern in the four games prior to the dismissal.

${ }^{13}$ For example, the home team's recent performance history prior to match day $t$ is $\left(y_{i t-1}, y_{i t-2}, y_{i t-3}, y_{i t-4}\right)$, where $y_{i t-k} \in\{3,1,0\}$ for $k=1 \ldots 4$ denotes the number of points gained in the match played $k$ match days before match day $t$. Proceeding analogously with the away team leads to $3^{4}=81$ of such history dummies for each team.

${ }^{14}$ We do not simply use absolute budget values as these have increased strongly over time, in both nominal and in real terms; for example, the average budget rose from 9.5 million Euro in season 1993/94 to 39.5 million for the season $2009 / 10$.

${ }^{15} \mathrm{~A}$ match is considered crucial for a team when, starting with the second half of the season (match days 18 through 34), its distance to either one of the ranks relevant for Championship and the UEFA
} 
Even though we control for the past performance of each team in a detailed manner, assumption (2) will still clearly be violated when the firing decision is based on unobservable variables determining the expected future performance of a team under its current or a new manager. For example, executives who decide on a dismissal will typically have observed further information (for instance from communication with influential players or by observing the team also between games) that should influence their decision. An important question is, for instance, whether a performance dip is only due to bad luck, while the team is in principle still in "good hands" under the current manager, or whether his relationship with the team is substantially disturbed.

To see that consider the following simple model. Suppose that prior to match day $t$ the executive receives a private signal $s_{i t}$ which contains some additional information on the team's expected subsequent performance, and that the latter is increasing in the signal, i.e. $\frac{\partial}{\partial s_{i t}} E\left[y_{i j t}(0) \mid n e w_{i t}=0, X_{i j t}, Y_{i j t}, s_{i t}\right]>0$. Suppose now that the coach will be dismissed (and thus newit $=1$ ) if and only if $E\left[y_{i j t}(0) \mid n e w_{i t}=0, X_{i j t}, Y_{i j t}, s_{i t}\right]$ is sufficiently small. In turn, this leads to a critical signal value $\bar{s}\left(X_{i j t}, Y_{i j t}\right)$ such that the coach is dismissed if and only if $s_{i t}<\bar{s}\left(X_{i t}, Y_{i t}\right)$. But then

$$
\begin{aligned}
& E\left[y_{i j t}(0) \mid n e w_{i t}=1, X_{i j t}, Y_{i j t}\right]=E\left[y_{i j t}(0) \mid s_{i t}<\bar{s}\left(X_{i j t}, Y_{i j t}\right), X_{i j t}, Y_{i j t}\right] \\
< & E\left[y_{i j t}(0) \mid s_{i t} \geq \bar{s}\left(X_{i j t}, X_{i j t}\right), X_{i j t}, Y_{i j t}, s_{i t}\right]=E\left[y_{i j t}(0) \mid n e w_{i t}=0, X_{i j t}, Y_{i j t}\right] .
\end{aligned}
$$

Hence, the conditional independence assumption (2) is violated and the estimates will be biased. But these considerations also lead to another insight, namely that the selection bias

$$
E\left[y_{i j t}(0) \mid n e w_{i t}=1, X_{i j t}, Y_{i j t}\right]-E\left[y_{i j t}(0) \mid n e w_{i t}=0, X_{i j t}, Y_{i j t}\right]
$$

is negative, and thus coefficients obtained from estimating specification (1) will be conservative in the sense that they under-estimate the true average treatment effect. The reason is that the teams in which managers are fired are those, whose performance under the old manager would be particularly low (as otherwise they would not have dismissed competitions or relegation is less or equal than 3 points. 
him). Those teams who did not fire the coach in the same situation should on average have a better performance - in turn, the true performance effect from a dismissal must be larger than the difference in performance between the dismissing and the non-dismissing teams. $^{16}$

Note that these considerations help to resolve a puzzle in the prior discussion about the effect of coach dismissals as there are two contradictory patterns: on the one hand, within-season dismissals are very frequent. ${ }^{17}$ But on the other hand, the existing studies mostly find negative or no effects of these dismissals, which would suggest highly irrational behavior on the part of the club executives because of the large cost associated with a dismissal in the form of payments to the outgoing coaches. ${ }^{18}$ As we have now argued, studies with observational data will most likely underestimate the effect of a dismissal. Hence, it may well be the case that coach dismissals may indeed more effective than previously thought. Moreover, the benefits of dismissals may depend on the degree of team heterogeneity. And it is this conjecture that we now explore in the remainder of this paper.

\subsection{Measuring Team Heterogeneity}

Our key hypothesis is that coach dismissals are more beneficial when teams are homogenous. In the regression model (1), the variables het ${ }_{i t}$ and het ${ }_{j t}$ are measures for team heterogeneity which are constructed as follows: We use performance grades which are assigned to individual players in each game on a 10 points scale where a higher value

\footnotetext{
${ }^{16}$ In an analogy to experiments, the estimation works as if a control group is constructed which on average has a systematically better performance outlook than the treatment group.

${ }^{17}$ Within-season managerial changes also occur frequently in other European soccer leagues such as England (on average for $28.6 \%$ of all teams), Spain (36.7\%), Italy (37\%), Portugal (54.6\%), Austria (63\%), Netherlands (38.4\%), Belgium (35.7\%). Managerial changes are also frequent in U.S. sports leagues, but within-season replacements are much less common: For example, only $10.2 \%$ of all teams in Major League Baseball had a within-season replacement during the period 1920 - 1973 (Allen, Panian, and Lotz, 1979). For the National Hockey League (NHL) the respective number is $18.4 \%$ during the period 1942/43 - 2001/02 (Rowe, Cannella, Rankin, and Gorman, 2005).

${ }^{18}$ As pointed out by Audas, Dobson, and Goddard (2002), while dismissals might not be effective on average, they tend to increase the variance of performance and hence might be optimal for teams facing the threat of relegation.
} 
indicates a better performance. ${ }^{19}$ In each match, each team fields 11 players, and it can replace up to three of these by players on the bench in the course of a match. ${ }^{20}$ For each team and each match day, we compute the average grade for each of its players in all matches prior to the match day and then rank players according to these average grades. Thereby, two groups of players will be of particular interest: those on rank positions 8 to 11 (i.e., the weakest ones among the top 11 players) and those at rank positions 12 to 15 (i.e., the strongest contenders), and the average grades of these two groups are denoted by $G_{t}^{8-11}$ and $G_{t}^{12-15}$, respectively. For each team and each match day, we then compute the ratio $g_{t}=\frac{G_{t}^{8-11}-G_{t}^{12-15}}{G_{t}^{8-11}}$ as a measure of how much worse on average the players on rank positions 12 to 15 are compared to those on positions 8 to 11 prior to match day $t .^{21}$

Because of the higher variance in prior grades early in a season the expected value of $g_{t}$ is decreasing in the match day of a given season. Therefore as a last step, for each match day we normalize the measure by dividing each team's $g_{t}$ by the average value across all teams at this match day. This normalized measure of team heterogeneity prior to match day $t$ is denoted $h_{t} t_{t}$, where $h_{t} t_{t}>(<) 1$ indicates a degree of heterogeneity above (below) average. When a team hires a new manager at match day $t$, we use $\frac{h e t_{t}+h e t_{t-1}}{2}$ (i.e. the team's average degree of heterogeneity of the last home and the last away match under the old manager) as a measure for the "inherited" team heterogeneity for the upcoming $\tau$ match types under the new manager. ${ }^{22}$

\footnotetext{
${ }^{19}$ These grades are assigned by Impire AG, Germany's largest professional provider of sports data services. Impire meticulously tracks each individual Bundesliga match and, for each player, records a number of performance variables, taking into consideration both position-specific factors (e.g. the number of assists per match for a striker or the number of saves for a goalkeeper), as well as teamspecific factors (e.g. the match result) which are then aggregated into the performance grade.

${ }^{20}$ The manager is not obliged to exhaust the maximum number of replacements ( 2 in the first two seasons of our sample, and 3 afterwards). In our sample, the number of replacements was at its maximum in 76.8 per cent of all matches.

${ }^{21}$ Our results are robust with respect to how broadly this set of "contested ranks" is defined.

${ }^{22}$ Teams alternate between home and away matches from one match day to the next. Given the different nature of the two match types (e.g., in terms of the result or playing strategy), it seems reasonable to take into account matches of either type when approximating the team heterogeneity which the new manager inherits from the old one. However, our results would not qualitatively change when using a different rule such as the predecessor's last match only or his last three or four matches. In any case, for our question of interest, the chosen measure of heterogeneity should be unaffected by
} 


\subsection{Descriptive Statistics}

\begin{tabular}{|c|c|c|c|c|c|c|}
\hline Variable & & Obs. & Mean & Std. Dev. & Min & $\operatorname{Max}$ \\
\hline \multirow[t]{2}{*}{ Points Home Team (result) } & & 5202 matches & 1.68 & 1.30 & 0 & 3 \\
\hline & $\begin{array}{r}\text { Home Win } \\
\text { Draw } \\
\text { Away Win }\end{array}$ & $\begin{array}{l}2463(47.35 \%) \\
1370(26.34 \%) \\
1369(26,32 \%)\end{array}$ & & & & \\
\hline Budget (relative) & & 306 team/seasons & 1 & 0.38 & 0.29 & 2.34 \\
\hline Roster Size & & 306 team/seasons & 25.74 & 2.75 & 19 & 35 \\
\hline \multirow[t]{2}{*}{ Managerial Change (new) } & Within-Season & 306 team/seasons & 0.48 & 0.74 & 0 & 3 \\
\hline & $\begin{array}{l}\text { Within-Season } \\
\text { Between-Season }\end{array}$ & $\begin{array}{l}17 \text { seasons } \\
17 \text { seasons }\end{array}$ & $\begin{array}{c}8.59 \\
3\end{array}$ & $\begin{array}{l}2.45 \\
2.09\end{array}$ & $\begin{array}{l}4 \\
1\end{array}$ & $\begin{array}{c}14 \\
9\end{array}$ \\
\hline \multirow[t]{2}{*}{ Performance (grade) } & & 9784 matches/team average & 6.02 & 0.80 & 3.64 & 8.42 \\
\hline & $\begin{array}{l}\text { home team } \\
\text { away team }\end{array}$ & $\begin{array}{l}4892 \\
4892\end{array}$ & $\begin{array}{l}6.28 \\
5.75\end{array}$ & $\begin{array}{l}0.74 \\
0.77\end{array}$ & $\begin{array}{l}3.79 \\
3.64 \\
\end{array}$ & $\begin{array}{l}8.42 \\
7.95\end{array}$ \\
\hline Team Heterogeneity (het) & & 288 team/seasons & 1 & 0.21 & 0.53 & 1.62 \\
\hline All matches & $\begin{array}{l}10 \% \text { percentile } \\
25 \% \text { percentile } \\
50 \% \text { percentile } \\
75 \% \text { percentile } \\
90 \% \text { percentile }\end{array}$ & 9486 matches & $\begin{array}{c}1 \\
0.57 \\
0.75 \\
0.97 \\
1.23 \\
1.46\end{array}$ & 0.34 & 0.08 & 2.65 \\
\hline $\begin{array}{l}\text { Last } 2 \text { matches of old } \\
\text { coach }\left(\frac{\text { het }_{t}+\text { het }_{t-1}}{2}\right)\end{array}$ & $\begin{array}{l}10 \% \text { percentile } \\
25 \% \text { percentile } \\
50 \% \text { percentile } \\
75 \% \text { percentile } \\
90 \% \text { percentile }\end{array}$ & 111 (upon dismissal) & $\begin{array}{l}0.98 \\
0.58 \\
0.68 \\
0.94 \\
1.20 \\
1.43\end{array}$ & 0.34 & 0.37 & 2.17 \\
\hline
\end{tabular}

Table 1: Descriptive Statistics

Table 1 summarizes the descriptive statistics for the main variables used in the analysis. As can be seen, match outcomes are not uniformly distributed, but the home team wins in about half of matches, while the other half is evenly split between draws and wins of the away team. Annual (relative) budgets are ranging from one third of the average budget to more than twice as much, which indeed suggests that teams are highly heterogeneous with respect to their ability to attract good players. ${ }^{23}$

There are no roster limits in the German Bundesliga and teams have rosters of up selection policy of the new coach.

${ }^{23}$ There are revenue-distribution mechanisms in place in the Bundesliga, but less so than in many US leagues, so that the income distribution tends to be more uneven. For example, while the TV rights are sold collectively and the revenue is then shared among all teams according to a pre-defined sharing rule, unlike many US leagues, there is no sharing of gate revenues which heavily favors the teams with the biggest stadiums. 
to 35 . The average roster size is 25 , i.e. the average team contracts with approximately twice as many players as it can field in a single match. While also the possibility of injuries needs to be taken into account, this suggests that within-team competition for the scarce slots in the squad is an importance aspect in this context. ${ }^{24}$ In fact, Figure 1 shows that match participation is strongly driven by players' rank within the roster in terms of prior performance, where for example, players in the top ranks are fielded more than three times as often as those on the lowest ranks.

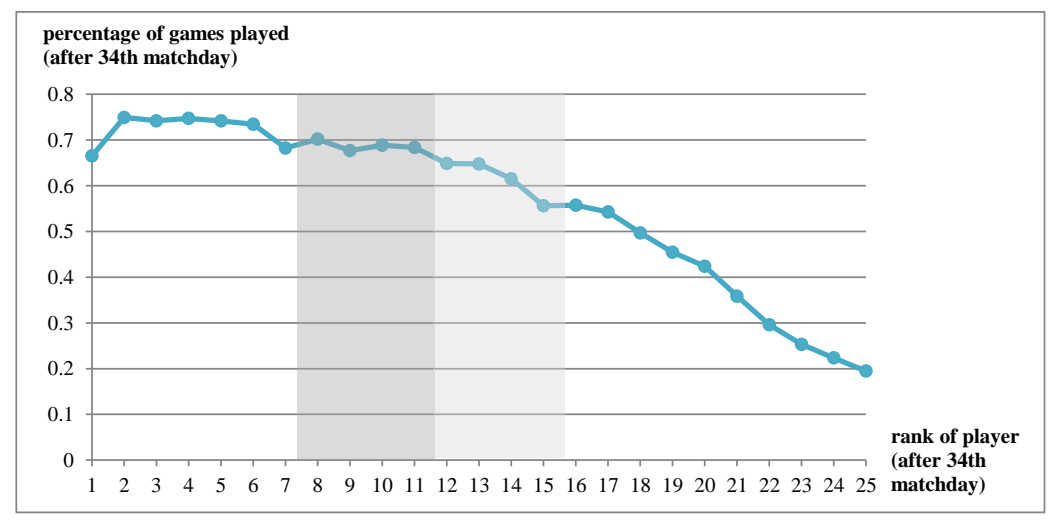

Figure 1: Performance Rank of Players and Participation

Table 1 also shows that teams differ strongly with respect to our (normalized) measure of heterogeneity based on grades (het): For example, the degrees of heterogeneity in the 90th- and 10th-percentile of the distribution differ by a factor 2.5. When confining attention to those cases involving a recent managerial change and comparing the degrees of heterogeneity which new managers inherit from their predecessors, this factor becomes even slightly stronger (2.7).

Figure 2 illustrates the average player performance (grades) in homogenous and heterogenous teams: As would be expected, heterogenous teams exhibit slightly better grades at the top performance ranks, while the grades in homogenous teams, being more balanced, are better at the lower ranks. Overall, these differences appear to be small. ${ }^{25}$

\footnotetext{
${ }^{24}$ Moreover, a player's salary will typically depend on how many times he has been fielded in a given seasons.

${ }^{25}$ This may for instance be due to the fact that team homogeneity comes with a cost. On the one
} 
While this suggests that heterogeneity in itself has no sizeable impact on performance, it will turn out that, consistent with our main hypothesis, it does become important when a manager is dismissed.

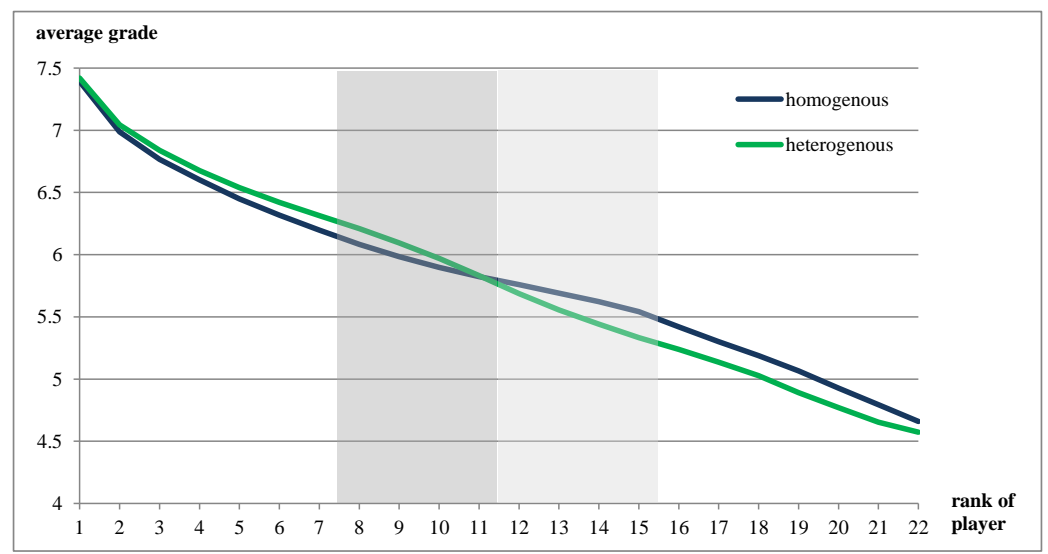

Figure 2: Average Grades and Team Heterogeneity

As for the frequency of dismissals, Table 1 shows that in about half of the 306 team-season observations, at least one dismissal occurred within the current season. At a season level, on average there were roughly 9 within-season dismissals. As already pointed out in the above, managerial change between two seasons occurs less often, on average only in 3 teams per season. Figure 3 presents more detailed information about the distribution of dismissals depending on a season's match day and league positions, respectively. It is evident from panel (b) that many dismissals occur when the respective teams are facing the threat of being relegated.

Finally, panel (a) of Figure 4 shows the average of the number of points won in the six games before and after dismissal for all teams with a within-season dismissal, suggesting a negative trend in performance as a key source of managerial change which points at the importance of controlling for the exact short-term sequence of performance to exclude

hand, the degree of within-team competition may be larger in homogenous teams. But on the other hand, the quality of the players at the lower ranks is more similar to those in the starting line-up so that, on a competitive labor market, the same must be true for their salaries. With a given budget, a more homogenous team will then be naturally associated with a lower average player quality in the starting line-up. 


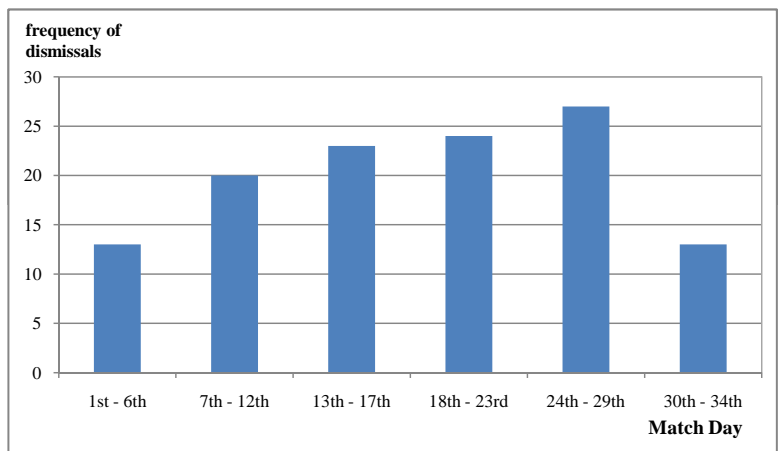

(a) Across Match Days

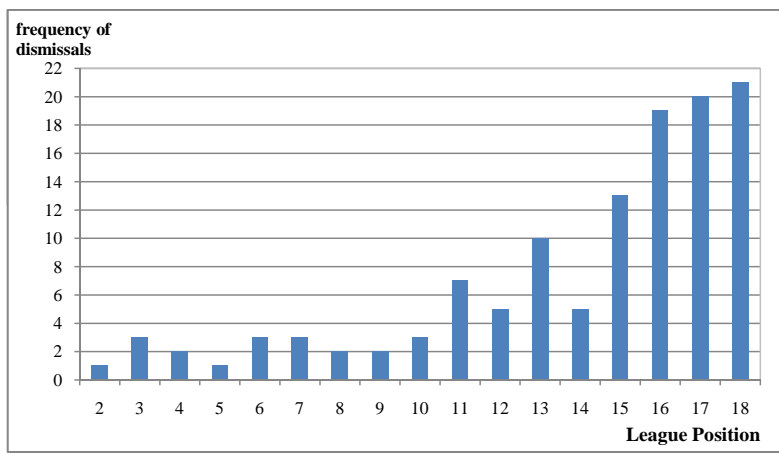

(b) Across League Positions

Figure 3: Distribution of Dismissals

mean reversion as a driver of the observed performance increase.

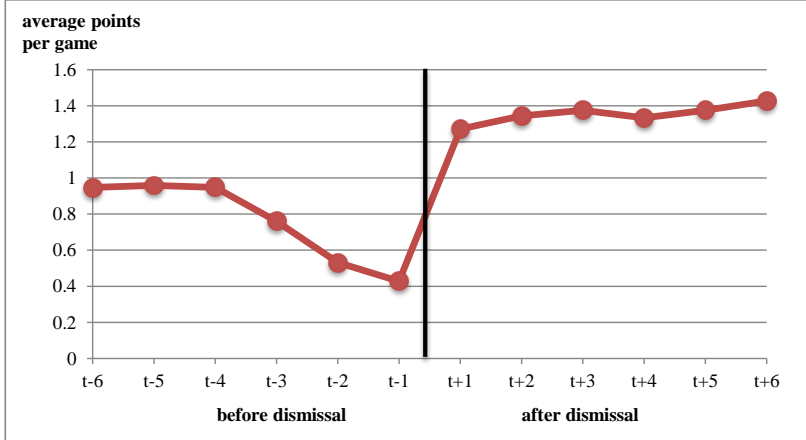

(a) All Teams

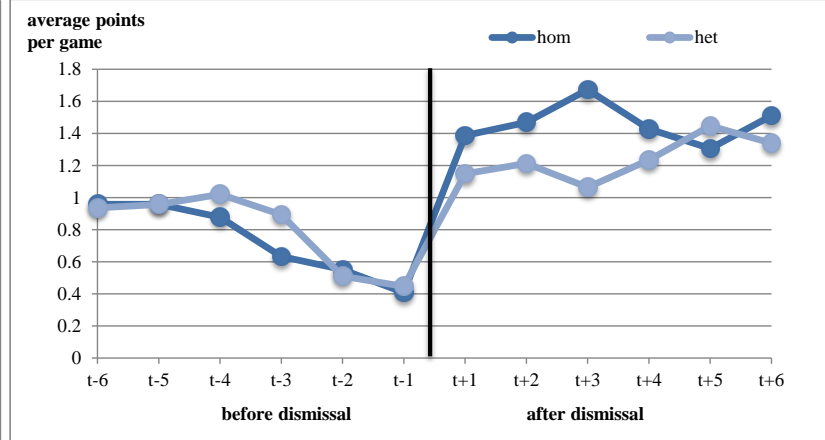

(b) Homogenous Versus Heterogenous Teams

Figure 4: Team Performance Before and After Dismissal

Importantly, our key hypothesis that positive succession effects emerge in homogenous rather than heterogenous teams, should not be driven by mean reversion. Rather, as argued by Höffler and Sliwka (2003), managerial change should be more successful in homogenous teams where it is easier for the new manager to re-vive the competition for the available slots as players are operating in a now more competitive environment. In contrast, when there is a large difference in abilities between the top players in the team and the rest, a new manager will basically have to pick the same starting line-up as his predecessor so that within-team competition cannot be triggered anew through a dismissal.

As a first step in assessing the validity of our main hypothesis, panel (b) of Figure 
4 plots again the average number of points achieved in the last six games before and after a dismissal but, in contrast to panel (a), separately for teams with above- and below-average values of heterogeneity. Strikingly, while both groups show a very similar performance dip prior to dismissal (with a slightly better performance for heterogenous teams), the performance increase in the first matches under the new manager is larger in homogenous teams. Moreover, the fact that this difference seems to vanish again after the first matches under the new manager is also in line with the theory: after some time in office, the new manager will again have made up his mind about his most preferred team composition and, in turn, within-team competition should again become weaker. These issues will be investigated in more detail in the following.

\section{Results}

\subsection{Coach Dismissals and Team Performance}

As explained above, we estimate lower boundaries to the causal effect of coach dismissals on team performance. Our main hypothesis is that dismissals should increase performance to a stronger extent in homogeneous teams. Note that we can test this hypotheses both with the data from home and away teams. In turn, we expect that the coefficient for the interaction term between our measure of heterogeneity (het) and the dummy for managerial change (new) should be negative for home teams and positive for away teams. We estimate three different models, looking at the new manager's first 2, 4 and 6 match types (home and away), respectively.

The regression results are shown in Table 2, and they provide strong support for the main hypothesis. All coefficients of the interaction terms have the expected sign and, with one exception, are also statistically significant. Moreover, and in line with the descriptive statistics (see Figure 2), heterogeneity in itself seems unrelated to performance; it plays a crucial role only when a manager is dismissed.

In a next step, we investigate the economic significance of the dismissal effect, depending on the degree of heterogeneity of the respective team. To do this we center the 


\begin{tabular}{|c|c|c|c|}
\hline & $\begin{array}{c}\text { Model } 1 \\
\text { short-term } \\
\quad(\tau=2)\end{array}$ & $\begin{array}{c}\text { Model } 2 \\
\text { intermediate-term } \\
(\tau=4)\end{array}$ & $\begin{array}{l}\text { Model } 3 \\
\text { long-term } \\
(\tau=6)\end{array}$ \\
\hline New_home & $\begin{array}{l}0.4823^{*} \\
(0.2757)\end{array}$ & $\begin{array}{c}0.4319 * * \\
(0.2106)\end{array}$ & $\begin{array}{c}0.4349 * * \\
(0.1806)\end{array}$ \\
\hline New_home ${ }^{*}$ het_home & $\begin{array}{c}-0.4853^{*} \\
(0.2562)\end{array}$ & $\begin{array}{c}-0.4532 * * \\
(0.2004)\end{array}$ & $\begin{array}{c}-0.4316^{* *} \\
(0.1725)\end{array}$ \\
\hline het_home & $\begin{array}{c}0.0848 \\
(0.0606)\end{array}$ & $\begin{array}{c}0.0852 \\
(0.0620)\end{array}$ & $\begin{array}{c}0.0887 \\
(0.0629)\end{array}$ \\
\hline New_away & $\begin{array}{c}-0.7359^{* * *} \\
(0.2627)\end{array}$ & $\begin{array}{c}-0.4239 * * \\
(0.2097)\end{array}$ & $\begin{array}{c}-0.3988^{* *} * \\
(0.1787)\end{array}$ \\
\hline New_away $*$ het_away & $\begin{array}{c}0.6518^{* * *} \\
(0.2523)\end{array}$ & $\begin{array}{c}0.3064 \\
(0.2017)\end{array}$ & $\begin{array}{c}0.3582^{* *} \\
(0.1717)\end{array}$ \\
\hline het_away & $\begin{array}{l}-0.0553 \\
(0.0590)\end{array}$ & $\begin{array}{l}-0.0562 \\
(0.0604)\end{array}$ & $\begin{array}{l}-0.0686 \\
(0.0617)\end{array}$ \\
\hline HomePerf_home & $\begin{array}{c}0.1451^{* * * *} \\
(0.0433)\end{array}$ & $\begin{array}{c}0.1434^{* * *} \\
(0.0437)\end{array}$ & $\begin{array}{c}0.1463^{* * *} \\
(0.0440)\end{array}$ \\
\hline AwayPerf_home & $\begin{array}{c}0.1225^{* * *} \\
(0.0390)\end{array}$ & $\begin{array}{c}0.1179 * * * \\
(0.0393)\end{array}$ & $\begin{array}{c}0.1169 * * * \\
(0.0395)\end{array}$ \\
\hline HomePerf_away & $\begin{array}{c}-0.1246^{* * *} \\
(0.0375)\end{array}$ & $\begin{array}{c}-0.1267^{* * *} \\
(0.0379)\end{array}$ & $\begin{array}{c}-0.1235^{* * *} \\
(0.0382)\end{array}$ \\
\hline AwayPerf_away & $\begin{array}{c}-0.1788^{* * *} \\
(0.0447)\end{array}$ & $\begin{array}{c}-0.1880^{* * *} \\
(0.0450)\end{array}$ & $\begin{array}{c}-0.1836^{* * * *} \\
(0.0454)\end{array}$ \\
\hline Perf_hist_home & $\begin{array}{l}-0.0050 \\
(0.0036)\end{array}$ & $\begin{array}{c}-0.0052 \\
(0.0036)\end{array}$ & $\begin{array}{l}-0.0050 \\
(0.0036)\end{array}$ \\
\hline Perf_hist_away & $\begin{array}{c}0.0096^{* * *} \\
(0.0035)\end{array}$ & $\begin{array}{c}0.0093^{* * *} \\
(0.0035)\end{array}$ & $\begin{array}{c}0.0097^{* * *} \\
(0.0035)\end{array}$ \\
\hline Budget_home & $\begin{array}{c}0.2745^{* * *} \\
(0.0683)\end{array}$ & $\begin{array}{c}0.2736^{* * *} \\
(0.0683)\end{array}$ & $\begin{array}{c}0.2766^{* * *} \\
(0.0682)\end{array}$ \\
\hline Budget_away & $\begin{array}{c}-0.2303^{* * *} \\
(0.0703)\end{array}$ & $\begin{array}{c}-0.2272^{* * *} \\
(0.0703)\end{array}$ & $\begin{array}{c}-0.2276^{* * *} \\
(0.0704)\end{array}$ \\
\hline Crucial_home & $\begin{array}{l}0.0790^{*} \\
(0.0454)\end{array}$ & $\begin{array}{l}0.0832^{*} \\
(0.0454)\end{array}$ & $\begin{array}{l}0.0802^{*} \\
(0.0456)\end{array}$ \\
\hline Crucial_away & $\begin{array}{c}-0.0138 \\
(0.0457)\end{array}$ & $\begin{array}{c}-0.0089 \\
(0.0458)\end{array}$ & $\begin{array}{l}-0.0106 \\
(0.0459) \\
\end{array}$ \\
\hline Past_Perf Dummies_home & yes & yes & yes \\
\hline Past_Perf Dummies_away & yes & yes & yes \\
\hline Season Dummies & yes & yes & yes \\
\hline Constant & $\begin{array}{c}1.8639 * * * \\
(0.5144)\end{array}$ & $\begin{array}{c}1.9163^{* * * *} \\
(0.5157)\end{array}$ & $\begin{array}{c}1.7176^{* * *} \\
(0.4521)\end{array}$ \\
\hline $\begin{array}{l}\text { Observations } \\
\text { Adjusted R-squared }\end{array}$ & $\begin{array}{l}4263 \\
0.080\end{array}$ & $\begin{array}{l}4259 \\
0.081\end{array}$ & $\begin{array}{l}4255 \\
0.081\end{array}$ \\
\hline
\end{tabular}

Table 2: Managerial Change and Team Heterogeneity 
het_home and het_away variables at different percentiles (10, 25, 75, 90 - see Table 1 for the respective values) of their distributions and then estimate again the New_home dummy, which then yields a lower bound on the average treatment effect in home games for teams at this percentile. To evaluate the effect of dismissals on away performance, Table 6 in the Appendix reports the results of a second regression with the same set of covariates, but with the number of points won by the away team as the dependent variable. $^{26}$ Applying the same approach to these models we obtain the average treatment effect in away games for teams at the respective percentiles. The overall average effect of a dismissal on the respective teams' performance per match of either type is then the average of the respective coefficients for New_home from Table 2 and New_away from Table 6 (centering the heterogeneity measure het at the respective percentile). The results are shown in Table $3 .^{27}$

As conjectured, Table 3 reveals that there are highly significant and substantial average dismissal effects (only) for homogenous teams, that is, at the lower percentiles of the distribution of het. For example, when a team with a degree of heterogeneity at the lowest $10(25) \%$ percentile replaces its manager, it wins on average an additional 0.31 (0.20) points per game during the next four matches (2 home and 2 away), compared to a team in a comparable situation which keeps its manager. Given that, at the time of dismissal, the average dismissing team has only won 0.98 points per match in the respective season (as opposed to an average in the whole sample of 1.68 points, see Table 1), these numbers indeed indicate substantial performance effects; a fortiori when recalling that, as argued above, the estimates are in fact lower bounds on the true causal effects.

\footnotetext{
${ }^{26}$ Note that the number of points lost by the home teams are not identical to the number of points gained by the away teams as the winner (loser) of a match gets 3 (0) points, while each team gets 1 point in case of a draw.

${ }^{27}$ For example, the entries in the first row $($ het $=0)$ are directly calculated as the average of the two coefficients in Tables 2 (New_home) and 6 (New_away), so that for the first column we get $\frac{1}{2}(0.4823+$ $0.8319)=0.6571$. Similarly, at the $25 \%$ percentile $($ where het $=0.75)$, we get $\frac{1}{2}(0.4823-(.04853 \cdot .75)+$ $0.8319-(0.7228 \cdot .75))=0.2029$. Because the set of covariates is identical in both estimations, we obtain the same coefficients when estimating a system of seeming unrelated regressions (SUR), see e.g., Greene (1997, pp. 676). This approach also allows us to test the joint significance of New_home (Table 2) and New_away (Table 6) which leads to the p-values as reported in the table.
} 


\begin{tabular}{|c|c|c|c|}
\hline & $\begin{array}{l}\text { Model H1 } \\
\text { short-term } \\
(2 \tau=4)\end{array}$ & $\begin{array}{c}\text { Model H2 } \\
\text { intermediate-term } \\
(2 \tau=8)\end{array}$ & $\begin{array}{l}\text { Model H3 } \\
\text { long-term } \\
(2 \tau=12)\end{array}$ \\
\hline $\begin{array}{l}\text { New } \\
(\text { het }=0)\end{array}$ & $\begin{array}{c}0.6571 * * * \\
(0.0003)\end{array}$ & $\begin{array}{c}0.4681^{* * *} * \\
(0.0008)\end{array}$ & $\begin{array}{c}0.4591^{* * *} \\
(0.0001)\end{array}$ \\
\hline $\begin{array}{l}\text { New } \\
(\text { het }=10 \% \text { percentile })\end{array}$ & $\begin{array}{c}0.3105^{* * *} * \\
(0.0014)\end{array}$ & $\begin{array}{c}0.2285^{* * * *} \\
(0.0017)\end{array}$ & $\begin{array}{c}0.2105^{* * *} \\
(0.0008)\end{array}$ \\
\hline $\begin{array}{l}\text { New } \\
(\text { het }=25 \% \text { percentile })\end{array}$ & $\begin{array}{c}0.2029 * * * \\
(0.0086)\end{array}$ & $\begin{array}{c}0.1541^{* * *} \\
(0.0077)\end{array}$ & $\begin{array}{c}0.1333^{* * *} \\
(0.0080)\end{array}$ \\
\hline $\begin{array}{l}\text { New } \\
(\text { het }=\text { mean })\end{array}$ & $\begin{array}{c}0.0531 \\
(0.4080)\end{array}$ & $\begin{array}{c}0.0506 \\
(0.3076)\end{array}$ & $\begin{array}{c}0.0258 \\
(0.5580)\end{array}$ \\
\hline $\begin{array}{l}\text { New } \\
(\text { het }=75 \% \text { percentile })\end{array}$ & $\begin{array}{l}-0.0838 \\
(0.2548)\end{array}$ & $\begin{array}{l}-0.0441 \\
(0.4588)\end{array}$ & $\begin{array}{l}-0.0724 \\
(0.1690)\end{array}$ \\
\hline $\begin{array}{l}\text { New } \\
(\text { het }=90 \% \text { percentile })\end{array}$ & $\begin{array}{c}-0.2232^{* *} \\
(0.0234)\end{array}$ & $\begin{array}{r}-0.1404^{*} \\
(0.0815)\end{array}$ & $\begin{array}{c}-0.1724^{* *} \\
(0.0143)\end{array}$ \\
\hline
\end{tabular}

Table 3: Average impact of managerial change on team performance at different percentiles of heterogeneity.

Moreover, and again in line with the descriptive observation (see panel (b) of Figure 4), the "new broom effect" becomes smaller as the time horizon considered for the new manager $(\tau)$ increases. Again, this is consistent with the idea that new manager's ability to trigger within-team competition anew is strongest in the first few matches of his new team.

Last, but not least, disentangling this overall average effect of a dismissal into home and away performance reveals that it is mainly driven by performance increases in away games. One interpretation for this result is that in home games the players' motivation is substantially higher in any case because of the monitoring, support or even pressure from the team's own fans (recall that home team wins occur twice as often as away wins and draws). Hence, the additional motivational push from intra-team competition from a coach replacement in a homogenous team seems to be stronger in away games where these other motivational mechanisms are weaker. 


\subsection{Coach Dismissals and Individual Players' Performance}

Apart from the performance impact of managerial succession on the (aggregate) team level, an alternative route is to directly consider the (individual) player level and see whether there is any measurable direct impact on the players' grades. Consistent with our underlying mechanism based on within-team competition, we would expect a stronger response of players in the "contested" ranks. i.e. those close to rank 11 which are the weakest players on the team or the strongest on the bench, but a weak response among the top players as they will most certainly also be part of the starting line up under a new coach. Moreover, as for the impact of team heterogeneity, this effect should be stronger in more homogenous teams.

In this respect, Figure 5 plots the changes of grades for the players at the different performance ranks (again using the average grades obtained so far) in response to dismissals. Panel (a) shows the change of (average) grades between the first 4 matches under the new manager and all previous matches (in a given season) under the old one, while panel (b) extends the time horizon to cover all matches under new manager until the end of the season. First note that the changes are increasing in a player's rank at the time of dismissal and are negative at the top ranks and positive at the lower ranks. This phenomenon is naturally explained by mean reversion of players who received top grades in the past have less scope to improve and vice-versa those at rather lower ranks have more scope for improvements. But the important observation here is that these differences are bigger in homogenous teams, in particular for those players in the contested ranks starting with rank 8. Moreover, from panel (b) and in line with our previous finding, we observe that the "new broom effect" seems to disappear after the tenure of the new manager increases.

To investigate this issue in more detail we estimated the performance change of individual players around a coach dismissal. We first constructed a data set containing all players of teams in which a coach has been replaced within a season. The dependent variable is the difference between the average grade in first 4 matches under new manager 


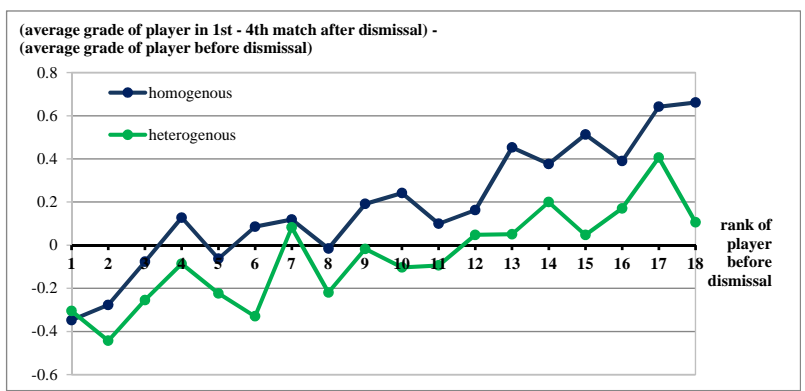

(a) First 4 Matches

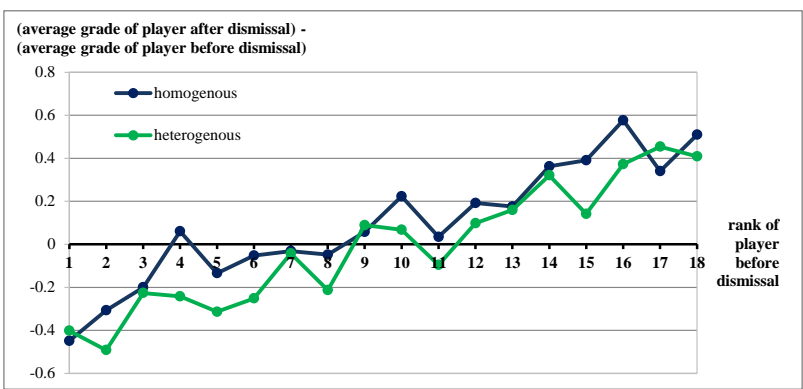

(b) All Matches

Figure 5: Change in Player Performance after Dismissal

and that in all matches (in a given season) under old one. The key independent variables are a dummy indicating whether the team's homogeneity is above average as well as the player's rank prior to the dismissal. The key hypotheses is that grade improvements due to coach replacements are stronger (i) in more homogenous teams and (ii) for players of lower ranks.

\begin{tabular}{|c|c|c|}
\hline & Model 4 & Model 5 \\
\hline Homogenous Dummy & $\begin{array}{c}0.2500^{* * *} \\
(0.0736)\end{array}$ & $\begin{array}{c}0.0904 \\
(0.1015)\end{array}$ \\
\hline Rank of player (before dismissal) & $\begin{array}{c}0.0499 * * * \\
(0.0048)\end{array}$ & $\begin{array}{c}0.0415^{* * *} \\
(0.0059)\end{array}$ \\
\hline Homogenous * Rank & & $\begin{array}{l}0.0150 * \\
(0.0085)\end{array}$ \\
\hline Shape & $\begin{array}{c}0.2387^{* *} \\
(0.0986)\end{array}$ & $\begin{array}{c}0.2398^{* *} \\
(0.0994)\end{array}$ \\
\hline Budget & $\begin{array}{c}0.0621 \\
(0.1080)\end{array}$ & $\begin{array}{c}0.0582 \\
(0.1082)\end{array}$ \\
\hline Perf_hist & $\begin{array}{l}-0.0089 \\
(0.0070)\end{array}$ & $\begin{array}{l}-0.0090 \\
(0.0070)\end{array}$ \\
\hline PointsAvg (current season) & $\begin{array}{c}-0.4711^{* * * *} \\
(0.1748)\end{array}$ & $\begin{array}{c}-0.4753^{* * *} \\
(0.1756)\end{array}$ \\
\hline Position Dummies & yes & yes \\
\hline Year Dummies & yes & yes \\
\hline Constant & $\begin{array}{l}-0.4018 \\
(0.2488)\end{array}$ & $\begin{array}{l}-0.3091 \\
(0.2538)\end{array}$ \\
\hline $\begin{array}{l}\text { Observations } \\
\text { Adjusted R-squared }\end{array}$ & $\begin{array}{l}1771 \\
0.103\end{array}$ & $\begin{array}{l}1771 \\
0.105\end{array}$ \\
\hline
\end{tabular}

Table 4: Impact of Dismissals on Individual Performance 
The regression results (with standard errors clustered on each separate coach dismissal) are shown in Table 4, and they confirm these hypotheses: As can be seen from the first column, the change in player performance as a result of managerial change is on average stronger for homogenous teams and for players at lower ranks (at the time of dismissal). More importantly, in the second column, we include an interaction term between team homogeneity and performance rank. This term is positive, thereby supporting the hypothesis that the change in performance at the more contested lower ranks is stronger for homogenous teams. Hence, managerial change seems most effective in this segment of the roster and for homogenous teams, as there the effect of better performance due to increased within-team competition is strongest. Note that these effects cannot driven by mean reversion, as in homogenous teams the players at these ranks tend to perform better prior to a replacement (see Figure 2), which makes it harder for them to attain further performance increases.

\subsection{The Impact of Team Heterogeneity Under Interim Man- agers}

Recall that we have excluded interim managers from the main analysis, because their spell was usually very short (on average a mere 2.3 matches) and, more importantly, they are typically known to be interim solutions, only responsible for the team until the arrival of the "real" replacement for the old manager and mostly they have worked for the same club before - typically as an assistant to the outgoing coach. Given their very short tenure as responsible coach and given that they are typically well acquainted with the players, our theory based on within-team competition would predict that new interim managers are less successful in triggering within-competition anew compared to those new managers who are hired from the outside and expected to stay for longer. ${ }^{28}$ As a result, and in contrast to our main findings as reported in Table 2, we should expect to see no sizeable effect of team heterogeneity on team performance when an interim coach takes over. Table 5 shows the results of the same regressions as above with an additional

\footnotetext{
${ }^{28}$ We are grateful to Loek Groot for this suggestion.
} 
dummy indicating whether or not the new manager is an interim coach. Indeed, the interaction terms are not significant for interim managers so that, in contrast to their more permanent counterparts, there is no effect with respect to team heterogeneity.

\section{Conclusion}

The allocation of tasks to subordinates is a core management responsibility not only in sports but nearly any kind of organization. When subordinates have preferences on tasks of different importance, subordinates compete for the most important tasks that for instance may help to advance their careers. And this competition can be a powerful incentive mechanism. However, it will crucially depend upon the manager's allocation choices. As shown by Höffler and Sliwka (2003), a manager who knows his subordinates very well will assign the most important tasks to the subordinate she perceives to be the most able. However, when this is transparent, competition among the subordinates will be rather weak as their roles are more or less fixed. In such a situation, dismissing the manager may trigger the competition for attractive tasks anew. A new manager who does not know the talents of her subordinates as precisely as her predecessor will have to make up her mind on the subordinates' talents. In turn the subordinates have a strong incentive to exert effort to convince the new manager of their abilities. We have explored this mechanism empirically in professional sports, a field where it should be of substantial importance as picking a subset of players from a larger team is a core management task of any coach. Our key hypothesis was that coach replacements have a stronger effect on team performance in more homogenous teams compared to heterogenous ones. Indeed we found that coach replacements are beneficial when the abilities of the weakest players just on the team and the strongest ones on the bench are similar.

This result has direct implications for the decision to replace coaches in professional sports. It is notable that in many sports, it is used as a key mechanism to boost performance in the short run, for instance to avoid relegation or to qualify for the prestigous UEFA leagues. As laid out above, in the German Bundesliga, one of the biggest football 


\begin{tabular}{|c|c|c|c|}
\hline & $\begin{array}{l}\text { Model } 7 \\
\text { short-term } \\
(\tau=1)\end{array}$ & $\begin{array}{c}\text { Model } 8 \\
\text { intermediate-term } \\
(\tau=2)\end{array}$ & $\begin{array}{c}\text { Model } 9 \\
\text { long-term } \\
(\tau=3)\end{array}$ \\
\hline New_home & $\begin{array}{c}0.8387^{* *} \\
(0.3586)\end{array}$ & $\begin{array}{l}0.4648^{*} \\
(0.2754)\end{array}$ & $\begin{array}{l}0.4236^{*} \\
(0.2354)\end{array}$ \\
\hline New_home ${ }^{*}$ het_home & $\begin{array}{c}-0.8277^{* *} \\
(0.3241)\end{array}$ & $\begin{array}{c}-0.4680^{*} \\
(0.2556)\end{array}$ & $\begin{array}{c}-0.4022^{*} \\
(0.2243)\end{array}$ \\
\hline het_home & $\begin{array}{c}0.0704 \\
(0.0595)\end{array}$ & $\begin{array}{c}0.0787 \\
(0.0603)\end{array}$ & $\begin{array}{c}0.0845 \\
(0.0610)\end{array}$ \\
\hline Interim_home & $\begin{array}{c}-1.5092 \\
(1.2677)\end{array}$ & $\begin{array}{c}-0.6349 \\
(1.1302)\end{array}$ & $\begin{array}{c}-0.5696 \\
(1.1339)\end{array}$ \\
\hline Interim_home $*$ het_home & $\begin{array}{c}1.4830 \\
(1.0410)\end{array}$ & $\begin{array}{c}0.6239 \\
(0.9497)\end{array}$ & $\begin{array}{c}0.4996 \\
(0.9567)\end{array}$ \\
\hline New_away & $\begin{array}{c}-0.9405^{* * *} \\
(0.3411)\end{array}$ & $\begin{array}{c}-0.7395^{* * *} \\
(0.2623)\end{array}$ & $\begin{array}{c}-0.4906^{* *} \\
(0.2348)\end{array}$ \\
\hline New_away $*$ het_away & $\begin{array}{c}0.8664^{* * * *} \\
(0.3247)\end{array}$ & $\begin{array}{c}0.6611^{* * * *} \\
(0.2518)\end{array}$ & $\begin{array}{l}0.3976^{*} \\
(0.2262)\end{array}$ \\
\hline het_away & $\begin{array}{l}-0.0461 \\
(0.0581)\end{array}$ & $\begin{array}{c}-0.0634 \\
(0.0590)\end{array}$ & $\begin{array}{c}-0.0620 \\
(0.0596)\end{array}$ \\
\hline Interim_away & $\begin{array}{c}0.8522 \\
(1.0809)\end{array}$ & $\begin{array}{c}0.8248 \\
(0.8037)\end{array}$ & $\begin{array}{c}0.8320 \\
(0.8018)\end{array}$ \\
\hline Interim_away $*$ het_away & $\begin{array}{l}-0.8018 \\
(0.8737)\end{array}$ & $\begin{array}{c}-0.4732 \\
(0.6685)\end{array}$ & $\begin{array}{l}-0.4824 \\
(0.6667)\end{array}$ \\
\hline HomePerf_home & $\begin{array}{c}0.1433^{* * *} \\
(0.0428)\end{array}$ & $\begin{array}{c}0.1450^{* * * *} \\
(0.0430)\end{array}$ & $\begin{array}{c}0.1458^{* * *} \\
(0.0433)\end{array}$ \\
\hline AwayPerf_home & $\begin{array}{c}0.1289^{* * * *} \\
(0.0387)\end{array}$ & $\begin{array}{c}0.1292^{* * *} \\
(0.0388)\end{array}$ & $\begin{array}{c}0.1285^{* * *} \\
(0.0390)\end{array}$ \\
\hline HomePerf_away & $\begin{array}{c}-0.1214^{* * *} \\
(0.0373)\end{array}$ & $\begin{array}{c}-0.1199 * * * \\
(0.0374)\end{array}$ & $\begin{array}{c}-0.1199 * * * \\
(0.0376)\end{array}$ \\
\hline AwayPerf_away & $\begin{array}{c}-0.1708^{* * *} \\
(0.0443)\end{array}$ & $\begin{array}{c}-0.1716^{* * *} \\
(0.0444)\end{array}$ & $\begin{array}{c}-0.1755^{* * * *} \\
(0.0446)\end{array}$ \\
\hline Perf_hist_home & $\begin{array}{l}-0.0054 \\
(0.0035)\end{array}$ & $\begin{array}{l}-0.0056 \\
(0.0035)\end{array}$ & $\begin{array}{l}-0.0056 \\
(0.0036)\end{array}$ \\
\hline Perf_hist_away & $\begin{array}{c}0.0106^{* * *} \\
(0.0035)\end{array}$ & $\begin{array}{c}0.0106^{* * * *} \\
(0.0035)\end{array}$ & $\begin{array}{c}0.0103^{* * *} \\
(0.0035)\end{array}$ \\
\hline Budget_home & $\begin{array}{c}0.2645^{* * *} \\
(0.0677)\end{array}$ & $\begin{array}{c}0.2655^{* * *} \\
(0.0677)\end{array}$ & $\begin{array}{c}0.2624^{* * *} \\
(0.0677)\end{array}$ \\
\hline Budget_away & $\begin{array}{c}-0.2158^{* * *} \\
(0.0702)\end{array}$ & $\begin{array}{c}-0.2181^{* * *} \\
(0.0700)\end{array}$ & $\begin{array}{c}-0.2178^{* * * *} \\
(0.0700)\end{array}$ \\
\hline Crucial_home & $\begin{array}{l}0.0754^{*} \\
(0.0453)\end{array}$ & $\begin{array}{l}0.0775^{*} \\
(0.0453)\end{array}$ & $\begin{array}{l}0.0774^{*} \\
(0.0454)\end{array}$ \\
\hline Crucial_away & $\begin{array}{l}-0.0069 \\
(0.0454)\end{array}$ & $\begin{array}{c}-0.0074 \\
(0.0455)\end{array}$ & $\begin{array}{l}-0.0061 \\
(0.0455)\end{array}$ \\
\hline Past_Perf Dummies_home & yes & yes & yes \\
\hline Past_Perf Dummies_away & yes & yes & yes \\
\hline Season Dummies & yes & yes & yes \\
\hline Constant & $\begin{array}{c}1.6625^{* * * *} \\
(0.4780)\end{array}$ & $\begin{array}{c}1.8840 * * * \\
(0.4413)\end{array}$ & $\begin{array}{c}1.4546^{* * *} \\
(0.4752)\end{array}$ \\
\hline $\begin{array}{l}\text { Observations } \\
\text { Adjusted R-squared }\end{array}$ & $\begin{array}{l}4320 \\
0.079\end{array}$ & $\begin{array}{l}4318 \\
0.079\end{array}$ & $\begin{array}{l}4316 \\
0.078\end{array}$ \\
\hline
\end{tabular}

Table 5: (Interim) Managerial Change and Team Heterogeneity 
leagues in the world and the largest in terms of the number of spectators nearly half of the clubs dismiss a coach at some point within a season. As our results show this can indeed be a reasonable policy - but only when within-team competition can be triggered by a dismissal which, as we have shown, is the case only when teams are rather homogenous. Hence, a simple rule of thumb implied by our results would be dismissal are more likely to beneficial when the respective team's players do not too differ substantially in terms of their quality. Indeed, club executives may intuitively have grasped some of this intuition as we find that $57 \%$ of all coach dismissals occur in teams with below average heterogeneity at the time of the dismissal.

But the result also contains some insights for other organizations. Firms frequently not only use dismissals, but also job rotation policies by exchanging managers across different functions or departments, to bring in "fresh air". Our results indicate that this can indeed reinvigorate the incentives of subordinates. But again an important caveat is that this mechanism only works when these subordinates are on a rather equal footing. If this is not the case the costs of a rotation or dismissal (for instance due to a loss in human capital or specific investments) may outweigh the gains. Our results also give some insights for the theory of tournaments or contests. A key theoretical result established in the literature on contests and tournaments is that competition creates the strongest incentives when players are rather homogenous. Our observations are well in line with this result. Moreover, the results hint at a mechanism how homogeneity can be increased in the real world even when the set of contestants cannot be changed: replacing the decision maker to reinvigorate the race for attractive positions by "destroying" some information on relative performance differences.

Finally, the paper also yields some methodological insights concerning the econometric evaluation of the effect of managerial change on performance. As we have pointed out, estimates in observational studies where proper instrumental variables are unavailable will be biased when executives who decide upon dismissals have further unobservable private information on future states. But as we have shown this mechanism induces a negative selection bias - and, in turn, typical regression models will underestimate 
the true effect. Hence, the fact that previous studies have typically found no or even negative effects does not tell us that coach dismissals are detrimental or useless. To the contrary, as suggested by our paper they can lead to substantial performance effects in homogenous teams. 


\section{Appendix}

\begin{tabular}{|c|c|c|c|}
\hline & $\begin{array}{l}\text { Model } 1 \\
\text { short-term } \\
(\tau=2)\end{array}$ & $\begin{array}{c}\text { Model } 2 \\
\text { intermediate- } \\
\text { term }(\tau=4)\end{array}$ & $\begin{array}{c}\text { Model } 3 \\
\text { long-term } \\
(\tau=6)\end{array}$ \\
\hline New_home & $\begin{array}{l}-0.3368 \\
(0.2631)\end{array}$ & $\begin{array}{c}-0.3354^{*} \\
(0.2011)\end{array}$ & $\begin{array}{c}-0.3017^{*} \\
(0.1706)\end{array}$ \\
\hline New_home $*$ het_home & $\begin{array}{c}0.3100 \\
(0.2450)\end{array}$ & $\begin{array}{l}0.3489^{*} \\
(0.1920)\end{array}$ & $\begin{array}{l}0.2817^{*} \\
(0.1629)\end{array}$ \\
\hline het_home & $\begin{array}{l}-0.0443 \\
(0.0579)\end{array}$ & $\begin{array}{l}-0.0467 \\
(0.0591)\end{array}$ & $\begin{array}{l}-0.0426 \\
(0.0601)\end{array}$ \\
\hline New_away & $\begin{array}{c}0.8319 * * * \\
(0.2518)\end{array}$ & $\begin{array}{c}0.5042 * * \\
(0.2040)\end{array}$ & $\begin{array}{c}0.4834 * * * \\
(0.1729)\end{array}$ \\
\hline New_away * het_away & $\begin{array}{c}-0.7228^{* * *} \\
(0.2318)\end{array}$ & $\begin{array}{c}-0.3818^{* *} \\
(0.1939)\end{array}$ & $\begin{array}{c}-0.4350^{* * *} \\
(0.1644)\end{array}$ \\
\hline het_away & $\begin{array}{c}0.0623 \\
(0.0566)\end{array}$ & $\begin{array}{c}0.0704 \\
(0.0578)\end{array}$ & $\begin{array}{c}0.0845 \\
(0.0592)\end{array}$ \\
\hline HomePerf_home & $\begin{array}{c}-0.1173 * * * \\
(0.0414)\end{array}$ & $\begin{array}{c}-0.1144^{* * * *} \\
(0.0417)\end{array}$ & $\begin{array}{c}-0.1184^{* * *} \\
(0.0421)\end{array}$ \\
\hline AwayPerf_home & $\begin{array}{c}-0.1069^{* * *} \\
(0.0369)\end{array}$ & $\begin{array}{c}-0.1021 * * * \\
(0.0372)\end{array}$ & $\begin{array}{c}-0.1024 * * * \\
(0.0374)\end{array}$ \\
\hline HomePerf_away & $\begin{array}{c}0.1014^{* * *} \\
(0.0356)\end{array}$ & $\begin{array}{c}0.1042^{* * * *} \\
(0.0359)\end{array}$ & $\begin{array}{c}0.1022^{* * *} \\
(0.0362)\end{array}$ \\
\hline AwayPerf_away & $\begin{array}{c}0.1779 * * * \\
(0.0427)\end{array}$ & $\begin{array}{c}0.1862^{* * * *} \\
(0.0430)\end{array}$ & $\begin{array}{c}0.1825 * * * \\
(0.0434)\end{array}$ \\
\hline Perf_hist_home & $\begin{array}{c}0.0042 \\
(0.0034)\end{array}$ & $\begin{array}{c}0.0044 \\
(0.0034)\end{array}$ & $\begin{array}{c}0.0042 \\
(0.0034)\end{array}$ \\
\hline Perf_hist_away & $\begin{array}{c}-0.0089^{* * *} * \\
(0.0033)\end{array}$ & $\begin{array}{c}-0.0086 * * * \\
(0.0033)\end{array}$ & $\begin{array}{c}-0.0089^{* * *} \\
(0.0033)\end{array}$ \\
\hline Budget_home & $\begin{array}{c}-0.2815^{* * *} \\
(0.0639)\end{array}$ & $\begin{array}{c}-0.2811 * * * \\
(0.0640)\end{array}$ & $\begin{array}{c}-0.2833^{* * *} \\
(0.0638)\end{array}$ \\
\hline Budget_away & $\begin{array}{c}0.2304^{* * *} * \\
(0.0682)\end{array}$ & $\begin{array}{c}0.2282^{* * * *} \\
(0.0683)\end{array}$ & $\begin{array}{c}0.2283 * * * \\
(0.0683)\end{array}$ \\
\hline Crucial_home & $\begin{array}{l}-0.0660 \\
(0.0431)\end{array}$ & $\begin{array}{l}-0.0702 \\
(0.0432)\end{array}$ & $\begin{array}{l}-0.0670 \\
(0.0433)\end{array}$ \\
\hline Crucial_away & $\begin{array}{c}0.0262 \\
(0.0437)\end{array}$ & $\begin{array}{c}0.0214 \\
(0.0438)\end{array}$ & $\begin{array}{c}0.0230 \\
(0.0439)\end{array}$ \\
\hline Past_Perf Dummies_home & yes & yes & yes \\
\hline Past_Perf Dummies_away & yes & yes & yes \\
\hline Season Dummies & yes & yes & yes \\
\hline Constant & $\begin{array}{l}0.8920^{*} \\
(0.5032) \\
\end{array}$ & $\begin{array}{l}0.8349^{*} \\
(0.5043) \\
\end{array}$ & $\begin{array}{l}1.0371^{* *} \\
(0.4312) \\
\end{array}$ \\
\hline $\begin{array}{l}\text { Observations } \\
\text { Adjusted R-squared }\end{array}$ & $\begin{array}{l}4263 \\
0.076\end{array}$ & $\begin{array}{l}4259 \\
0.076\end{array}$ & $\begin{array}{l}4255 \\
0.076\end{array}$ \\
\hline
\end{tabular}

Table 6: Impact of Managerial Change and Team Heterogeneity in Away Games 


\section{References}

Allen, M., S. Panian, and R. Lotz (1979): "Managerial succession and organizational performance: A recalcitrant problem revisited," Administrative Science Quarterly, 24(2), 167-180.

Angrist, J., And J. Pischke (2008): Mostly harmless econometrics: An empiricist's companion. Princeton University Press.

Ashenfelter, O. (1978): "Estimating the effect of training programs on earnings," The Review of Economics and Statistics, 60(1), 47-57.

Audas, R., S. Dobson, And J. Goddard (1999): "Organizational Performance and Managerial Turnover," Managerial and Decision Economics, 20, 305-318.

- (2002): "The impact of managerial change on team performance in professional sports," Journal of Economics and Business, 54(6), 633-650.

Audas, R., J. Goddard, And S. Dobson (1997): "Team Performance and Managerial Change in the English Football League," Economic Affairs, 17(3), 30-36.

BAIK, K. (1994): "Effort Levels in Contests with Two Asymmetric Players.," Southern Economic Journal, 61(2).

Barros, C., B. Frick, And J. PAssos (2009): "Coaching for survival: the hazards of head coach careers in the German 'Bundesliga'," Applied Economics, 41(25), 33033311.

Berger, J., And P. Nieken (2010): "Heterogeneous Contestants and Effort Provision in Tournaments - An Empirical Investigation with Professional Sports Data, mimeographed," University of Bonn, SFB/TR 15 Discussion Paper No. 325.

Brown, J. (2011): "Quitters never win: The (adverse) incentive effects of competing with superstars," Journal of Political Economy, 119(5), 982-1013. 
Brown, M. (1982): "Administrative succession and organizational performance: The succession effect," Administrative Science Quarterly, 27(1), 1-16.

Bruinshoofd, A., And B. Ter Weel (2003): "Manager to go? Performance dips reconsidered with evidence from Dutch football," European Journal of Operational Research, 148(2), 233-246.

Clark, D. J., And C. RiIs (2000): "Allocation Efficiency in a Competitive Bribery Game," Journal of Economic Behavior \&6 Organization, 42, 109-124.

DE Dios Tena, J., And D. Forrest (2007): "Within-season dismissal of football coaches: Statistical analysis of causes and consequences," European Journal of Operational Research, 181(1), 362-373.

De Paola, M., And V. Scoppa (2012): "The effects of managerial turnover: evidence from coach dismissals in Italian soccer teams," Journal of Sports Economics, 13(2), $152-168$.

FABIANIC, D. (1994): "Managerial Change and Organizational Effectiveness in Major League Baseball: Findings for the Eighties.," Journal of Sport Behavior, 17(3), 139152.

Feess, E., G. Muehlheusser, and M. Walzl (2008): "Unfair Contests," Journal of Economics, 93(3), 267-291.

Fullerton, R., And R. P. McAfee (1999): "Auctioning Entry into Tournaments," Journal of Political Economy, 107, 573-605.

Gamson, W., And N. Scotch (1964): "Scapegoating in Baseball," American Journal of Sociology, 70(1), 69-72.

Gradstein, M. (1995): "Intensity of competition, entry and entry deterrence in rent seeking contests," Economics \& Politics, 7(1), 79-91.

Greene, W. H. (1997): Econometric analysis. Prentice Hall, Upper Saddle River. 
Grusky, O. (1963): "Managerial Succession and Organizational Effectiveness," American Journal of Sociology, 69(1), 21-31.

Heckman, J., R. LaLonde, and J. Smith (1999): "The economics and econometrics of active labor market programs," Handbook of Labor Economics, 3, 1865-2097.

HÖFfler, F., And D. Sliwka (2003): "Do new brooms sweep clean? When and why dismissing a manager increases the subordinates' performance," European Economic Review, 47(5), 877-890.

KAHn, L. (2000): "The Sports Business as a Labor Market Laboratory," Journal of Economic Perspectives, 14(3), 75-94.

Lazear, E., and S. Rosen (1981): "Rank-Order Tournaments as Optimum Labor Contracts," Journal of Political Economy, 89(5), 841-864.

LiEn, D. D. (1990): "Corruption and Allocation Efficiency," Journal of Development Economics, 33, 153-164.

LYNCH, J. (2005): "The effort effects of prizes in the second half of tournaments," Journal of Economic Behavior and Organization, 57(1), 115-129.

McPherson, B. (1976): "Involuntary Turnover: A Characteristic Process of Sport Organizations," International Review for the Sociology of Sport, 11(4), 5-16.

McTeer, W., P. White, and S. Persad (1995): "Manager Coach Mid-Season Replacement and Team Performance in Professional Team Sport.," Journal of Sport Behavior, 18(1), 58-68.

Moldovanu, B., And A. Sela (2006): "Contest Architecture," Journal of Economic Theory, 126(1), 70-97.

Nalebuff, B., And J. Stiglitz (1983): "Prizes and incentives: towards a general theory of compensation and competition," The Bell Journal of Economics, pp. 21-43. 
Nickell, S. (1981): "Biases in dynamic models with fixed effects," Econometrica, 49(6), $1417-1426$.

Nieken, P., And M. Stegh (2010): "Incentive Effects in Asymmetric Tournaments Empirical Evidence from the German Hockey League," University of Bonn, SFB/TR 15 Discussion Paper No .305.

Nti, K. (1999): "Rent-seeking with asymmetric valuations," Public Choice, 98(3), 415430.

O'Keeffe, M., W. Viscusi, and R. Zeckhauser (1984): "Economic contests: Comparative reward schemes," Journal of Labor Economics, 2(1), 27-56.

Orrison, A., A. Schotter, And K. Weigelt (2004): "Multiperson tournaments: An experimental examination," Management Science, 50, 268-279.

Porter, P., And G. Scully (1982): "Measuring managerial efficiency: the case of baseball," Southern Economic Journal, 48(3), 542-550.

Rowe, W., A. Cannella, D. Rankin, and D. Gorman (2005): "Leader succession and organizational performance: Integrating the common-sense, ritual scapegoating, and vicious-circle succession theories," The Leadership Quarterly, 16(2), 197-219.

Schotter, A., and K. Weigelt (1992): "Asymmetric tournaments, equal opportunity laws, and affirmative action: Some experimental results," The Quarterly Journal of Economics, 107(2), 511-539.

SCUlly, G. (1994): "Managerial efficiency and survivability in professional team sports," Managerial and Decision Economics, 15(5), 403-411.

Sunde, U. (2009): "Heterogeneity and performance in tournaments: a test for incentive effects using professional tennis data," Applied Economics, 41(25), 3199-3208.

Szymanski, S., and T. Valletti (2005): "Incentive effects of second prizes," European Journal of Political Economy, 21(2), 467-481. 
TAYlor, C. (1995): "Digging for Golden Carrots: an Analysis of Research Tournaments," American Economic Review, 85(4), 872-890.

Theberge, N., And J. Loy (1976): "Replacement Processes in Sport Organizations: the Case of Professional Baseball," International Review for the Sociology of Sport, 11(2), 73-93. 